\title{
Cellular and humoral immune responses associated with protection in sheep vaccinated against Teladorsagia circumcincta
}

\author{
Cynthia Machín ${ }^{1}$, Yolanda Corripio-Miyar², Julia N. Hernández ${ }^{1 *}$ C , Tara Pérez-Hernández ${ }^{1}$, Adam D. Hayward², \\ Harry W. Wright ${ }^{2}$, Daniel R. G. Price ${ }^{2}$, Jacqueline B. Matthews ${ }^{3}$, Tom N. McNeilly², Alasdair J. Nisbet ${ }^{2}$ and \\ Jorge F. González
}

\begin{abstract}
Due to increased anthelmintic resistance, complementary methods to drugs are necessary to control gastrointestinal nematodes (GIN). Vaccines are an environmentally-friendly and promising option. In a previous study, a Teladorsagia circumcincta recombinant sub-unit vaccine was administered to two sheep breeds with different levels of resistance against GIN. In the susceptible Canaria Sheep (CS) breed, vaccinates harboured smaller worms with fewer eggs in utero than the control group. Here, we extend this work, by investigating the cellular and humoral immune responses of these two sheep breeds following vaccination and experimental infection with T. circumcincta. In the vaccinated CS group, negative associations between antigen-specific $\lg A, \lg G_{2}$ and Globule Leukocytes (GLs) with several parasitological parameters were established as well as a higher $\mathrm{CD} 4^{+} / \mathrm{CD}^{+}$ratio than in control $\mathrm{CS}$ animals, suggesting a key role in the protection induced by the vaccine. In the more resistant Canaria Hair Breed (CHB) sheep the vaccine did not significantly impact on the parasitological parameters studied and none of these humoral associations were observed in vaccinated $\mathrm{CHB}$ lambs, although $\mathrm{CHB}$ had higher proportions of $\mathrm{CD} 4^{+}$and $\mathrm{CD} 8^{+} \mathrm{T}$ cells within the abomasal lymph nodes, suggesting higher mucosal T cell activation. Each of the component proteins in the vaccine induced an increase in immunoglobulin levels in vaccinated groups of each breed. However, levels of immunoglobulins to only three of the antigens (TCi-MEP-1, TCi-SAA-1, TCi-ASP-1) were negatively correlated with parasitological parameters in the CS breed and they may be, at least partially, responsible for the protective effect of the vaccine in this breed. These data could be useful for improving the current vaccine prototype.
\end{abstract}

Keywords: Nematode vaccine, Genetic resistance, Immune response, Immunoglobulins, Globule leukocytes, Teladorsagia circumcincta, Sheep, Cellular response

\section{Introduction}

The protective immune response in sheep against Teladorsagia circumcincta infection has been studied extensively and is associated with lower worm egg production

\footnotetext{
*Correspondence: julia.hernandez@ulpgc.es

${ }^{1}$ Facultad de Veterinaria, Instituto Universitario Sanidad Animal y

Seguridad Alimentaria, Universidad de Las Palmas de Gran Canaria, Arucas, Spain

Full list of author information is available at the end of the article
}

and parasite burden, as well as shorter and less fecund female adult nematodes $[1,2]$. A predominantly Type- 2 response has been implicated in this immune response, recruiting eosinophils, mast cells, globule leukocytes (GL), with concomitant production of parasite-specific IgA, IgG and IgE as well as some cytokines such as IL-4 and IL-5 [3]. Associations between the nematode specific IgA levels and reduced worm length and worm eggs in utero (EIU) in T. circumcincta infections have been reported $[1,2,4,5]$.

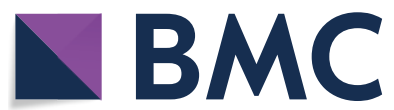

c The Author(s) 2021. This article is licensed under a Creative Commons Attribution 4.0 International License, which permits use, sharing, adaptation, distribution and reproduction in any medium or format, as long as you give appropriate credit to the original author(s) and the source, provide a link to the Creative Commons licence, and indicate if changes were made. The images or other third party material in this article are included in the article's Creative Commons licence, unless indicated otherwise in a credit line to the material. If material is not included in the article's Creative Commons licence and your intended use is not permitted by statutory regulation or exceeds the permitted use, you will need to obtain permission directly from the copyright holder. To view a copy of this licence, visit http://creativeco mmons.org/licenses/by/4.0/. The Creative Commons Public Domain Dedication waiver (http://creativecommons.org/publicdomain/ zero/1.0/) applies to the data made available in this article, unless otherwise stated in a credit line to the data. 
Until recently, control of $T$. circumcincta has been focused on the use of chemotherapeutics, but nematode resistance against anthelmintics has made this approach unsustainable [6]. Due to this issue, it is important to find alternative control measures, such as vaccination; understanding the mechanisms underlying the protective immune response is essential for the development of a successful vaccine [7]. Although finding a successful prototype recombinant vaccine against gastrointestinal nematodes (GINs) has been a difficult task, a recombinant sub-unit vaccine against $T$. circumcincta was recently developed and has shown repeated effectiveness [7-10]. Previous successful prototype vaccines against GIN were only effective in their native forms, preventing global distribution and commercialisation. This recombinant prototype has some features which could overcome this hurdle but, as with other prototype recombinant vaccines against GINs, repeated trials have shown variability in protective response [9]. In addition, the combination of 8 antigens in a single vaccine makes its production prohibitively expensive and simplifying the vaccine would be very desirable.

In a recent study [11], parasitological data was collected for evaluating the effects of this vaccine in two sheep breeds, the Canaria Sheep (CS) and the Canaria Hair Breed (CHB), which have different susceptibilities to T. circumcincta. Whereas in vaccinated CS animals there were significant reductions in worm length and numbers of worm intrauterine eggs, vaccination in $\mathrm{CHB}$ also induced reductions in parasitological variables, but these were not statistically significant. Here, as an extension of this study, we report the main immune responses that were found in vaccinated sheep. Data obtained would help increase the efficacy of the prototype vaccine and bring it nearer to market.

\section{Materials and methods}

\section{Animals and experimental design}

The experimental design was previously described in details in [11]. Briefly, 24 male lambs of $\mathrm{CHB}$ and another 24 male lambs of CS, all of them weaned, were dewormed and kept worm-free until they were six months-old. These animals were randomly selected, within each breed, to establish 4 groups (CHB-vaccine, CHB-control, CS-vaccine and CS-control) of 12 lambs in separated pens. One animal from the vaccinated group of $\mathrm{CHB}$ died for non-related causes before the experimental procedures began.

Vaccinated groups (CHB-vaccine and CS-vaccine) were injected subcutaneously (3 doses, on days 0, 21 and 42) with $400 \mu \mathrm{g}$ of antigens [given as 2 injections: one with cathepsin F-1 (Tci-CF-1), a $20 \mathrm{kDa}$ protein of unknown function (Tci-ES20), activation-associated secretory protein-1 (Tci-ASP-1), a homologue of a protective antigen from Ancylostoma caninum (Tci-SAA-1), macrophage migration inhibitory factor-1 (Tci-MIF-1), calcium-dependent apyrase-1 (Tci-APY-1) and a TGF $\beta$ homologue (Tci-TGH-2) in PBS; and the other with astacin-like metalloproteinase-1 (Tci-MEP-1) in PBS/ Urea] plus $10 \mathrm{mg}$ Quil A (Vax Saponin, Guinness Chemical Products Ltd) [8]. Control groups received the same volume of urea/PBS/10 mg Quil A each time. At the same time as the final immunisation (day 42), a "trickle infection" protocol was carried out where all animals were inoculated with 2000 third stage larvae (L3) of T. circumcincta three times per week for 4 weeks until day 68 .

Faecal egg counts (FEC) were performed using modified McMaster technique [12] three times per week from day 56 after the start of immunisations, until the end of the experiment. At the end of the trial (days 82-85), lambs were euthanised, and adult and immature worms from aliquots of the abomasal content were obtained, counted and measured following standard techniques [11].

\section{Enzyme-linked immunosorbent assay}

Animals were bled from the jugular vein on day 77 following the first immunisation, four days prior to postmortem. These samples were collected in silicone-coated tubes (Gel+Clot Act. VenoSafe ${ }^{\mathrm{TM}}$, TERUMO) for blood serum and were refrigerated at $4{ }^{\circ} \mathrm{C}$ for at least $30 \mathrm{~min}$. Then, they were centrifugated at $1164 \times g$ (Mixtasel, Selecta) and the serum obtained kept at $-20{ }^{\circ} \mathrm{C}$ until use. ELISA was performed to determine levels of IgA, IgG and $\mathrm{IgG}_{2}$ in sera from individual sheep following a previously published protocol [13] with minor modifications. Microplates $\left(\right.$ Corning $\left.^{\circledR}\right)$ were coated overnight at $4{ }^{\circ} \mathrm{C}$ with $5 \mu \mathrm{g} / \mathrm{mL}$ of antigen (L4 and adult stage of T. circumcincta; or individual recombinant antigens from the vaccine) in carbonate buffer $(50 \mu \mathrm{L}$ per well). All incubations were done at $37{ }^{\circ} \mathrm{C}$. After three washes with Phosphate Buffered Saline (PBS) $+0.05 \%$ Tween 20 and blocking for $1 \mathrm{~h}$ with 3\% bovine serum albumin in PBS, samples diluted at 1:200 in Tris Buffered Saline containing $0.05 \%$ Tween ${ }^{\circledR} 20$ (TBST) were incubated for $1 \mathrm{~h}$ (each sample was performed in duplicate). Following a further wash, mouse anti-sheep IgA (1:8000 in TBST for parasite antigens and 1:4000 for vaccine antigens), $\operatorname{IgG}_{1}$ or $\mathrm{IgG}_{2}$ (clones McM1 and McM3 respectively, at 1:1000 in TBST) were added and incubated for $1 \mathrm{~h}$. Plates were then washed and polyclonal rabbit anti-mouse immunoglobulins conjugated to HRP (Dako) added at 1:1000 and incubated for $1 \mathrm{~h}$. After a final wash step, $100 \mu \mathrm{L}$ of O-phenylene-diamine dihydrochloride substrate (Sigma Fast OPD Tablets) was added to each well (final concentrations of $0.4 \mathrm{mg} / \mathrm{ml}$ OPD, $0.4 \mathrm{mg} / \mathrm{ml}$ urea hydrogen 
peroxide, and $0.05 \mathrm{M}$ phosphate-citrate) and the reaction stopped by adding $25 \mu \mathrm{L}$ of $2 \mathrm{M}$ sulphuric acid. Finally, Optical Density (OD) values were read at $490 \mathrm{~nm}$ (Multiskan Ascent). A serum sample from a non-infected animal was included as a negative control, while the positive control sera was obtained from trickle infected vaccinated animals from this trial. The optical densities were transformed into an optical density index (ODI) for each animal using the formula: $\mathrm{ODI}=($ mean $\mathrm{OD}-$ mean negative OD)/(mean positive OD-mean negative OD) [14], adding 1.0 to all values to avoid negative data for statistical analysis.

\section{Lymphocyte stimulation assays}

Abomasal lymph node (ALN) cells were collected aseptically at post-mortem (days 82-85) in cold transport wash media [TWM (HBSS w/o $\mathrm{Ca}^{2+}$ or $\mathrm{Mg}^{2+}$ supplemented with $2 \%$ heat inactivated foetal calf serum (FCS), 100U/ $\mathrm{mL}$ penicillin, $100 \mu \mathrm{g} / \mathrm{mL}$ streptomycin and $2 \%$ gentamicin, all from Sigma)] and kept on ice until processing. In order to obtain single cell suspensions from the ALN, lymph nodes were rinsed with fresh cold TWM, placed in a petri dish and cleaned from excess adipose tissue. Around $3 \mathrm{~mL}$ of fresh TWM was added to the petri dish, and tissue was then dissociated using a sterile syringe plunger. Cell suspension was then filtered through $70 \mu \mathrm{m}$ cell strainers to remove large clumps and tissue fragments. Samples were allowed to settle for $10 \mathrm{~min}$ and any debris/excess cells discarded. Following two washes with TWM, cell suspensions were frozen in freezing media (FBS $+10 \%$ cell culture grade DMSO (Sigma)) and stored in liquid nitrogen until processed. Prior to stimulations, frozen cells were gently defrosted in a water bath and warm complete media (RPMI-1640 medium supplemented with 10\% FCS, $2 \mathrm{mM} \mathrm{L-glu-}$ tamine, $100 \mathrm{U} / \mathrm{mL}$ Penicillin, $100 \mu \mathrm{g} / \mathrm{mL}$ Streptomycin, $0.5 \%$ of gentamicin and $50 \mu \mathrm{M} 2$-mercaptoethanol (all from Sigma)) gently added to the vials. Cells were then washed twice with fresh media and re-suspended at $2 \times 10^{6}$ cells $/ \mathrm{mL}$. Lymphocyte stimulation assays (LSA) were carried out by incubating $2 \times 10^{5} \mathrm{ALN}$ cells in triplicate with equal volumes of PBS (negative control), ConA (positive control), soluble L4 T. circumcincta or Adult $T$. circumcincta antigen (all stimulants at $5 \mu \mathrm{g} / \mathrm{mL}$ final concentration), in a total volume of $200 \mu \mathrm{L}$, at $37{ }^{\circ} \mathrm{C}$ with $5 \%$ $\mathrm{CO}_{2}$ in air for 5 days. After 4 days, $50 \mu \mathrm{L}$ of media from each replicate was collected and stored at $-20{ }^{\circ} \mathrm{C}$ for cytokine measurements and replenished with fresh complete media containing methyl- ${ }^{3} \mathrm{H}$ thymidine $(0.5 \mu \mathrm{Ci}$ per well). Proliferation was measured by the incorporation of methyl- ${ }^{3} \mathrm{H}$ thymidine during the final $18 \mathrm{~h}$ of culture and expressed as Stimulation Index (SI) by dividing the proliferation of samples incubated with $T$. circumcinta antigen by that from PBS controls.

\section{Cytokine ELISA}

Capture ELISAs were performed to examine the antigen specific secretion of interferon (IFN)- $\gamma$ Interleukin (IL)-4 and IL-17A by ALN. All incubations were carried out at room temperature unless stated otherwise. Interleukin-4 and IFN- $\gamma$ were quantified using commercial ELISA kits according to the manufacturer's instructions (MABTECH $\mathrm{AB}$, Augustendalsvägen, SE, Sweden). For the quantification of IL-17A, polyclonal rabbit anti-bovine IL-17A antibodies were used alongside bovine recombinant protein (all from Kingfisher Biotech, Inc., St. Paul, MN). Washing steps for all ELISAs were performed 6 times with $350 \mu \mathrm{L}$ washing buffer (Phosphate Buffered Saline (PBS) $+0.05 \%$ Tween $\left.{ }^{\circledR} 20\right)$ using a Thermo Scientific Wellwash ${ }^{\mathrm{T} M}$ Versa (ThermoFisher). Briefly, high-binding capacity ELISA plates (Immunolon ${ }^{\mathrm{TM}}$ 2HB 96-well microtiter plates, ThermoFisher) were incubated with coating antibodies overnight at $4{ }^{\circ} \mathrm{C}$. Plates were then washed and blocked for $1 \mathrm{~h}$ with PBS containing $0.05 \%$ Tween ${ }^{\circledR} 20$ (Sigma, UK) and 0.1\% BSA Bovine Serum Albumin (BSA, Sigma, $\mathrm{UK})$. Following a further washing step, $50 \mu \mathrm{L}$ of supernatants or standards were added in duplicate for $1 \mathrm{~h}$. Subsequently, plates were washed, and detection antibodies added for $1 \mathrm{~h}$. This was followed by washing and addition of Streptavidin-HRP (Dako, Agilent, Santa Clara, USA) for $45 \mathrm{~min}$. After the final washing step, $50 \mu \mathrm{L}$ of SureBlue TMB substrate (Insight Biotechnology, London, UK) was added and the reaction was stopped by the addition of equal volume of TMB stop solution (Insight Biotechnology, London, UK). Absorbance values were read at OD $450 \mathrm{~nm}$ using a Sunrise ${ }^{\mathrm{TM}}$ microplate reader (Tecan, Männedorf, $\mathrm{CH}$, Switzerland). In order to quantify the cytokines of interest, samples were analysed 1:2 for IFN- $\gamma$ or neat for IL-4 and IL-17A. All values were blanked corrected and concentrations determined from the standard curves included in all plates which were constructed using 7 serial dilutions of recombinant cytokines ranging from 400 to $6.25 \mathrm{pg} / \mathrm{mL}$ for IFN- $\gamma$ (MABTECH AB); 2000 to $62.5 \mathrm{pg} / \mathrm{mL}$ for IL-4 (MABTECH AB) and 1500 to $23.43 \mathrm{pg} / \mathrm{mL}$ for IL-17A (Kingfisher).

\section{Phenotyping of ALN cells by flow cytometry}

Single colour flow cytometry was carried out in resuscitated ALN cells using the monoclonal antibodies detailed in Additional file 1 at pre-optimised concentrations. All incubations were carried out at room temperature and protected from light. Briefly, $5 \times 10^{5}$ ALN cells per antigen/no antibody control/secondary only control were blocked with $200 \mu \mathrm{L}$ of $20 \%$ heat inactivated normal goat serum (BioRad) for $15 \mathrm{~min}$. Following centrifugation, 
supernatants were discarded and cells incubated with their corresponding antibody or FACS buffer (PBS + 5\% heat inactivated FCS plus $0.02 \%$ sodium azide) for controls for $20 \mathrm{~min}$. Cells were then washed twice with FACS buffer and incubated with anti-mouse IgG $(\mathrm{H}+\mathrm{L})$ conjugated to Alexa Fluor ${ }^{\circledR} 647$ (Invitrogen, Life Technologies, USA) for $20 \mathrm{~min}$. After two washes, cells were resuspended in dead cell stain Sytox Blue (Invitrogen, Life Technologies, USA) prior to acquisition. A minimum of 25000 events were acquired using a MACSQuant ${ }^{\circledR}$ Analyzer 10 (Miltenyi Biotech, Germany) and analysed using FlowJo vX for Windows 7. Dead cell and doublet cell discrimination was performed during all analysis.

\section{Histochemistry and morphometric analysis}

Abomasal tissue samples (approximately $2 \mathrm{~cm} \times 2 \mathrm{~cm}$ ) were collected at post-mortem from the antropyloric region for histological and immunohistochemistry studies, performed as described previously [15]. Eosinophil and globule leukocyte (GL) counts were performed in abomasal tissue stained with haematoxylin and eosin (Additional file 2), while toluidine blue staining was used to determine mast cell numbers. For each animal sample, cells were counted in at least 20 randomly selected fields of $0.06 \mathrm{~mm}^{2}(0.245 \mathrm{~mm} \times 0.245 \mathrm{~mm})$ at $400 \times$ magnification with an optical microscope (Olympus CX31) and expressed as cell $/ \mathrm{mm}^{2}$. Eosinophils and mast cells were counted in selected fields in the lamina propria corresponding to the lower third of the abomasal mucosa. Globule leukocytes were counted in the upper third of the mucosa.

The tissue samples taken for immunohistochemistry were used to identify and count the following cell populations: $\mathrm{CD}^{+}, \mathrm{CD}^{+}, \gamma \delta \mathrm{TCR}^{+}, \mathrm{MHCII}^{+}, \mathrm{CD} 45 \mathrm{RA}^{+}$and Galectin- $14^{+}$(Additional file 1) [15]. Cells were counted in 20 fields located in upper and lower third of the mucosa and were expressed in cells $/ \mathrm{mm}^{2}$, as described above (Additional file 2).

\section{Statistical analysis}

IBM SPSS Statistics version 24.0 software was used for statistical analysis of parasitological, immunohistochemical and serum antibody data. Differences in FEC, cumulative FEC, worm counts, worm length and EIU were estimated as described in [11]. The data relative to specific immunoglobulin levels in serum were analysed using generalised linear models (GENLIN), using the estimation method Newton-Raphson and Pearson Chi-square scale. The general linear model (GLM) univariate was used for cellular counts, taking LSD (Least Significance Difference) test as reference.

Analyses for immune cell phenotypes were performed using RStudio package version 1.1.456 ( $\mathrm{R}$ Core Team 2019) as follows: flow cytometry and proliferation data was analysed using two-way ANOVA to test for differences between breeds, vaccination groups (control, vaccinated), and their interaction. Cytokine data was analysed using a GLM as follows: IFN- $\gamma$ and IL-4 data was log-transformed prior to analysis to satisfy normality of residuals and homoscedasticity. Both cytokines were fitted with effects of vaccine, breed and antigenstimulation (treatment), as well as two-way interactions and the three-way interaction. Models were simplified by stepwise deletion based on Wald F-tests.

Spearman's rank correlation coefficient was used for studying correlations between immunological, cellular and parasitological variables.

For all analyses, probabilities of $p<0.05$ were considered statistically significant. One animal from CScontrol group was excluded from all statistical analyses because the abomasal wash sample was lost, meaning no worm burden data was available. Figures were produced with RStudio package version 1.1.456.

\section{Results}

\section{Parasitological data}

Parasitological data from this trial was previously presented in [11]. Briefly, vaccination induced a statistically significant reduction in worm length and EIU in the vaccinated CS group when compared to the control (adjuvant-only) CS group (Table 1).

Table 1 Parasitological data from Canaria Sheep (CS) and Canaria Hair Breed (CHB) sheep vaccinated with a prototype recombinant sub-unit Teladorsagia circumcincta vaccine and subsequently challenged with $T$. circumcincta

\begin{tabular}{lclll}
\hline Group & Cumulative FEC & Worm burden & Worm length (mm) & ElU \\
\hline CS Vac & $2861 \pm 737$ & $3606 \pm 803$ & $9.10 \pm 0.10^{* *}$ & $16.39 \pm 0.77^{* *}$ \\
CS Con & $4372 \pm 1021$ & $4148 \pm 761$ & $9.87 \pm 0.06^{* *}$ & $23.67 \pm 0.87^{* *}$ \\
CHB VaC & $720 \pm 205$ & $1171 \pm 459$ & $8.82 \pm 0.12$ & $14.65 \pm 0.73$ \\
CHB Con & $1157 \pm 503$ & $2052 \pm 548$ & $9.07 \pm 0.09$ & $16.03 \pm 0.67$ \\
\hline
\end{tabular}

Values shown are Means ( \pm SEM) and values with statistically significant differences within breeds are represented with "**" at $p<0.01$. Abbreviations: Vac: Vaccinated, Con: Control (adjuvant-only), FEC: Faecal egg count; EIU: Eggs in utero. Data obtained from González et al. [11]. 


\section{Measurement of antibody responses to parasite and vaccine antigens in serum}

In order to evaluate if the vaccine has induced some variations in the humoral immune response against this worm, the response to the L4 stage -target of the protective immunity in sheep- was firstly analysed in vaccinated and non-vaccinated infected groups of both breeds. Immunoglobulin A was the only isotype for which a statistically significant increase, associated with vaccination, against L4 antigen was observed, in the vaccinated $\mathrm{CHB}$ group $(p<0.01)$ compared to the $\mathrm{CHB}$ control group (Table 2). Negative correlations between levels of L4 extract-specific serum IgA and $\operatorname{IgG}_{2}$ and worm length or EIU were observed in vaccinated groups, being only statistically significant in the CS vaccine recipients. Levels of $L 4$ extract specific IgG $_{2}$ were also negatively associated with worm burden and cumulative FEC in CS vaccine recipients (Table 2 ).

Specific IgA, IgG $\operatorname{Ig}_{1}$ and $\operatorname{IgG}_{2}$ levels in serum against all recombinant antigens were significantly higher in the vaccinated sheep than in control sheep (Table 3, Additional files 3, 4, 5, 6, 7 and 8). Specific serum IgA levels against all studied recombinant antigens were very similar within breeds, though levels of IgA specific for Tci-CF-1 were significantly lower than those against Tci-APY-1 in vaccinated CS animals (Additional files 3 and 4). Greater variability in vaccinated groups was observed in the levels of specific $\operatorname{IgG}_{1}$ and $\operatorname{IgG}_{2}$ against these recombinant proteins within breeds (Table 3, Additional files 3, 4, 5, 6, 7 and 8 ). In vaccinated $C S, \operatorname{IgG}_{1}$ levels specific for Tci-CF-1 and Tci-SAA-1 were similar and were significantly higher than $I_{g} G_{1}$ levels against the other recombinant proteins, although $\operatorname{IgG}_{1}$ against Tci-MEP-1 was not significantly lower than Tci-SAA-1-specific IgG . IgG $_{1}$ levels against Tci-MEP-1 were significantly higher than IgG $_{1}$ levels specific for Tci-ES20 and Tci-APY-1. On the contrary, IgG specific for Tci-MIF-1 was significantly lower than IgG $_{1}$ specific for Tci-ASP-1, Tci-ES20, Tci-MEP-1 and TciTGH-2 (Additional file 5). In vaccinated CHB animals, levels of $\operatorname{IgG}_{1}$ specific for all recombinant antigens were similar, except for Tci-MIF-1 and Tci-SAA-1, which were not significantly different to each other, but were significantly lower than the other antigens (Additional file 6). Specific $\operatorname{IgG}_{2}$ levels against all vaccine proteins were variable in both breeds; represented in Additional files 7 and 8. In vaccinated CS animals, levels of Tci-ASP-1 were significantly higher than $\operatorname{IgG}_{2}$ levels against the other recombinant proteins, except Tci-SAA-1. Levels of $\operatorname{IgG}_{2}$ specific for Tci-MIF-1 were lower than most of the other proteins. In general, specific levels of this immunoglobulin isotype against all proteins were variable and individual differences between antigens were recorded. In

Table 2 Levels of serum immunoglobulins against extracts of the fourth larval stage (L4) of Teladorsagia circumcincta in Canaria Sheep (CS) and Canaria Hair Breed (CHB) sheep vaccinated with a prototype recombinant sub-unit T. circumcincta vaccine and subsequently challenged with $T$. circumcincta

\begin{tabular}{|c|c|c|c|c|c|c|}
\hline Isotype & Group & Mean \pm SEM & Cumulative FEC & Worm burden & Worm length & EIU \\
\hline \multicolumn{7}{|c|}{ Correlation } \\
\hline \multirow[t]{6}{*}{$\lg A$} & $\mathrm{CS}$ & $1.189 \pm 0.054$ & -0.223 & 0.016 & -0.333 & -0.267 \\
\hline & CSVac & $1.160 \pm 0.066$ & -0.371 & -0.545 & $-0.776^{* *}$ & $-0.615^{*}$ \\
\hline & CSCon & $1.220 \pm 0.089$ & 0.027 & 0.542 & -0.023 & 0.255 \\
\hline & $\mathrm{CHB}$ & $1.335 \pm 0.073$ & -0.077 & -0.335 & 0.065 & -0.007 \\
\hline & CHBVac & $1.509 \pm 0.124^{* *}$ & -0.545 & -0.600 & 0.042 & -0.212 \\
\hline & CHB Con & $1.175 \pm 0.055^{* *}$ & 0.263 & 0.259 & 0.203 & 0.224 \\
\hline \multirow[t]{6}{*}{$\lg G 1$} & $\mathrm{CS}$ & $1.547 \pm 0.057$ & -0.033 & 0.191 & 0.050 & 0.120 \\
\hline & CSVac & $1.508 \pm 0.151$ & 0.224 & 0.084 & -0.238 & -0.182 \\
\hline & CSCon & $1.590 \pm 0.145$ & -0.164 & 0.436 & 0.164 & 0.564 \\
\hline & $\mathrm{CHB}$ & $1.305 \pm 0.103$ & 0.107 & -0.179 & 0.259 & 0.234 \\
\hline & CHBVac & $1.312 \pm 0.063$ & -0.227 & -0.191 & 0.261 & 0.261 \\
\hline & CHB Con & $1.300 \pm 0.095$ & 0.305 & -0.042 & 0.196 & 0.245 \\
\hline \multirow[t]{6}{*}{$\lg G 2$} & $\mathrm{CS}$ & $1.241 \pm 0.047$ & -0.158 & 0.037 & -0.190 & -0.239 \\
\hline & CSVac & $1.234 \pm 0.070$ & $-0.594^{*}$ & $-0.594^{*}$ & $-0.867^{* *}$ & $-0.825^{* *}$ \\
\hline & CSCon & $1.249 \pm 0.064$ & 0.227 & $0.782^{* *}$ & 0.291 & 0.473 \\
\hline & $\mathrm{CHB}$ & $1.205 \pm 0.050$ & 0.345 & 0.012 & $0.448^{*}$ & $0.655^{* *}$ \\
\hline & CHBVac & $1.255 \pm 0.092$ & 0.327 & 0.073 & 0.406 & $0.733^{*}$ \\
\hline & CHB Con & $1.160 \pm 0.046$ & 0.261 & 0.042 & 0.483 & $0.578^{*}$ \\
\hline
\end{tabular}

Antibody levels are expressed as optical density index (ODI) value $+1(\mathrm{ODI}+1)$. Associations are expressed as Spearman's correlation coefficient. Statisticallysignificant differences within breeds for a specific isotype and antigen and significant correlations are represented with "**" at $p<0.05$ and "**" at $p<0.01$. 
Table 3 Levels of serum immunoglobulins against a subset of recombinant vaccine proteins in Canaria Sheep (CS) and Canaria Hair Breed (CHB) sheep vaccinated with a prototype recombinant sub-unit Teladorsagia circumcincta vaccine and subsequently challenged with $T$. circumcincta

\begin{tabular}{|c|c|c|c|c|c|c|c|}
\hline Isotype & Antigen & Group & Mean \pm SEM & Cumulative FEC & Worm burden & Worm length & EIU \\
\hline \multicolumn{8}{|c|}{ Correlation } \\
\hline \multirow[t]{4}{*}{$\lg A$} & TCi-MEP-1 & CSVac & $1.656 \pm 0.058^{* *}$ & -0.364 & $-0.650^{*}$ & -0.497 & $-0.706^{*}$ \\
\hline & & CS Con & $1.188 \pm 0.045^{* *}$ & 0.473 & $0.727^{*}$ & 0.309 & 0.109 \\
\hline & & CHBVac & $1.652 \pm 0.071^{* *}$ & -0.073 & -0.582 & -0.321 & -0.358 \\
\hline & & CHB Con & $1.246 \pm 0.085^{* *}$ & 0.109 & 0.399 & 0.385 & -0.021 \\
\hline \multirow[t]{8}{*}{$\lg G 1$} & TCi- ASP-1 & CS Vac & $1.877 \pm 0.043^{* *}$ & -0.399 & -0.196 & -0.392 & $-0.636^{*}$ \\
\hline & & CS Con & $0.991 \pm 0.004^{* *}$ & -0.405 & 0.223 & -0.087 & 0.219 \\
\hline & & $\mathrm{CHBVac}$ & $1.683 \pm 0.067^{*}$ & 0.155 & -0.036 & -0.285 & -0.358 \\
\hline & & CHB Con & $1.017 \pm 0.013^{*}$ & 0.494 & 0.126 & 0.308 & 0.406 \\
\hline & TCi- SAA-1 & CS Vac & $2.104 \pm 0.086^{* *}$ & -0.552 & -0.252 & $-0.699^{*}$ & $-0.608^{*}$ \\
\hline & & CS Con & $0.995 \pm 0.002^{* *}$ & 0.018 & -0.027 & -0.391 & -0.600 \\
\hline & & $\mathrm{CHBVac}$ & $1.478 \pm 0.089^{*}$ & -0.191 & -0.118 & -0.152 & -0.612 \\
\hline & & CHB Con & $0.999 \pm 0.001^{*}$ & 0.182 & 0.280 & -0.119 & -0.098 \\
\hline \multirow[t]{4}{*}{$\lg G 2$} & TCi- ASP-1 & CS Vac & $2.004 \pm 0.049^{* *}$ & -0.399 & -0.329 & -0.392 & $-0.587^{*}$ \\
\hline & & CS Con & $0.998 \pm 0.003^{* *}$ & -0.100 & -0.073 & -0.182 & 0.509 \\
\hline & & $\mathrm{CHBVaC}$ & $1.701 \pm 0.059^{*}$ & 0.164 & -0.118 & -0.067 & -0.164 \\
\hline & & CHB Con & $1.004 \pm 0.001^{*}$ & 0.067 & 0.112 & 0.028 & -0.021 \\
\hline
\end{tabular}

Antibody levels are expressed as $(\mathrm{ODI}+1)$. Only the antigens for which correlations with parasitology variables were established are shown in the table. Associations are expressed as Spearman's correlation coefficient. Statistically-significant differences within breeds for a specific isotype and antigen and significant correlations are represented with "*" at $p<0.05$ and "**" at $p<0.01$.

vaccinated $\mathrm{CHB}$, the individual variability was also high: Specific IgG 2 levels against Tci-MEP-1 were higher than all the other proteins except Tci-CF-1. On the contrary, specific IgG $_{2}$ levels of Tci-MIF-1 were significantly lower than $\mathrm{IgG}_{2}$ levels of all the other vaccine antigens. Detailed significances in $\operatorname{IgG}_{2}$ levels specific for the other recombinant proteins in CHB are presented in Additional file 8.

Specific IgA levels against Tci-MEP-1 in the serum of vaccinated CS animals were negatively correlated with adult worm burden $(p<0.05)$ and EIU $(p<0.05)$ (Table 3$)$. Levels of specific IgG $_{1}$ against Tci-SAA-1 in the serum of vaccinated CS animals were also negatively correlated with worm length and EIU $(p<0.05)$ and, in this group, levels of specific $\operatorname{IgG}_{1}$ and $\operatorname{IgG}_{2}$ against Tci-ASP-1 correlated negatively with EIU $(p<0.05)$ (Table 3$)$. No other antigen-specific immunoglobulin isotype in any other vaccinated group was negatively correlated with any parasitological parameter (Additional files 3, 4, 5, 6, 7 and 8).

\section{Cellular responses}

Abomasal lymph node (ALN) cells from vaccinated animals from both breeds generally showed higher mean proliferative responses to $T$. circumcincta adult somatic antigen compared to L4 somatic antigen (Figure 1). No significant differences in antigen specific proliferation were observed between vaccinated or control animals for either breed, and no vaccine $\mathrm{x}$ breed interaction was observed.

Supernatant from antigen-stimulated ALN were harvested on day 4 post-stimulation and levels of IFN- $\gamma$ and IL-4 quantified. Significantly higher levels of IFN- $\gamma$ were present in ALN cells stimulated with both T. circumcincta adult and L4 antigens compare to unstimulated controls $(\mathrm{F}=3.72, \mathrm{DF}=2, p=0.027$; Figure 2A). There was no evidence of an effect of breed or vaccination status, nor any interactions between vaccination and breed, although mean IFN- $\gamma$ production was higher in antigenstimulated ALN cells from CHB sheep. Similarly, IL-4 release was significantly higher in ALN cells stimulated with adult and L4 antigens compared to unstimulated controls $(\mathrm{F}=34.98$, DF $=2, p<0.001$; Figure 2B) but again there was no evidence of a main effect of breed or vaccination status, nor an interaction between vaccination and breed.

Antigen-specific IL-17A release was not detected in any of the ALN cultures (data not shown).

When the phenotype of the ALN cells was investigated by flow cytometry, significant effects of the vaccine and breed were identified. The proportions of $\mathrm{CD}_{4}^{+}$ $\mathrm{T}$ cells within ALN cell populations were higher in CHB sheep compared to CS sheep ( $\mathrm{F}=4.42, p=0.042)$, which appeared largely driven by the control animals (Figure 3A). Similarly, the proportion of $\mathrm{CD}^{+} \mathrm{T}$ cells 


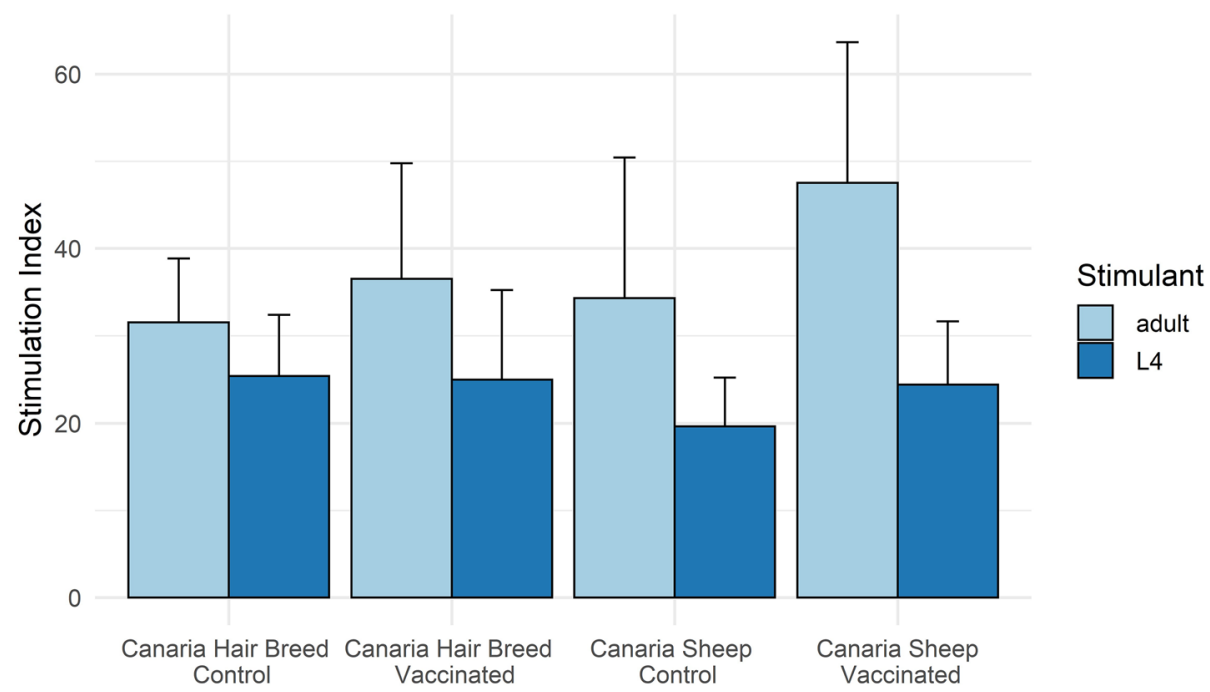

Figure 1 Antigen specific proliferation in Abomasal Lymph Nodes from Canaria Sheep and Canaria Hair Breed sheep vaccinated with a prototype recombinant sub-unit Teladorsagia circumcincta vaccine and subsequently challenged with $T$. circumcincta. Abomasal Lymph Nodes were collected at post-mortem and lymphocytes stimulated with $5 \mathrm{~g} / \mathrm{mL}$ of T. circumcincta L 4 or adult somatic antigen for 5 days. Proliferation was measured by the incorporation of methyl- ${ }^{3} \mathrm{H}$ thymidine $\left(\left[{ }^{3} \mathrm{H}\right] \mathrm{TdR} ; 0.5 \mu \mathrm{Ci}\right.$ per well) for the final $18 \mathrm{~h}$ of culture. Data are presented as the stimulation index with error bars denoting $\pm S E$.

was also significantly higher in $\mathrm{CHB}$ sheep $(\mathrm{F}=8.72$, $p=0.005$; Figure $3 \mathrm{~B}$ ), and were also higher in controls compared to vaccinated groups $(\mathrm{F}=10.74, p<0.002)$. The proportion of $\mathrm{CD}_{14}{ }^{+}$cells were higher in $\mathrm{CHB}$ sheep $(\mathrm{F}=5.72, p=0.022$; Figure $3 \mathrm{G})$. Finally, the $\mathrm{CD} 4^{+}: \mathrm{CD} 8^{+}$ ratio was affected by both breed and vaccination, with higher $\mathrm{CD}^{+}: \mathrm{CD}^{+}$ratios observed in the $\mathrm{CS}$ breed $(\mathrm{H}=4.52, p=0.04)$ and in vaccinated animals $(\mathrm{F}=9.77$, $p=0.003$ ) (Figure $3 \mathrm{H}$ ).

No differences in mean values of eosinophils, mast cell, GLs, $\mathrm{CD}^{+}, \mathrm{CD}^{+}, \mathrm{CD} 45 \mathrm{RA}^{+}, \mathrm{MHCII}^{+}, \gamma \delta^{+}$and galectin- $14^{+}$populations in the abomasal mucosa were observed between vaccinated and non-vaccinated animals of either breed (Figures 4 and 5). Globule leukocyte (GL) levels showed negative correlations with several parasitological variables analysed in all groups, but particularly in vaccinated CS animals in which GL levels were negatively associated with all of the parasitology measures recorded (Table 4). No other cell population studied in vaccinated groups showed a negative association with parasitology in any group (Additional files 9 and 10).

\section{Discussion}

Naturally or experimentally-induced protection against T. circumcincta following infection is a complex phenomenon in which several immunoglobulins such as IgA, IgE, IgG, cells such as eosinophils, mast cells, globule leukocytes (GL), $\mathrm{CD} 4^{+}$, plasmatic cells and other factors, like IL-4 and/or 5 or galectins are implicated. Although the main "actors" of this response are well-known, there is great variability in the phenotype of immunity. Part of this variability is a consequence of host factors such as age, breed, genetic resistance, but also parasite factors such as stage of worm development and level of burden [3].

The fact that lambs naturally acquire protective immunity against GIN after continual field-infection, underpinned the concept of developing a vaccine against these types of pathogens (recently reviewed in Britton et al. [16]). But, because of the complexity of the protective mechanisms involved in natural immunity, it is a challenge to recreate these with a recombinant subunit vaccine. Certainly, several promising antigens have been identified, but most of them share similar limitations: (1) it may not be possible to produce them as effective recombinant antigens; (2) there is individual variability in protection conferred by vaccines [9]. Recently, a recombinant prototype against T. circumcincta was identified which successfully protected lambs and periparturient ewes [7, 8]. However, individual variability in responses was observed. Furthermore, a reduction in the number of immunogens would be desirable for decreasing vaccine production cost. This type of reductionist strategy needs to be led by an understanding of vaccine-induced immunity and, if possible, immunological correlates of protection. 

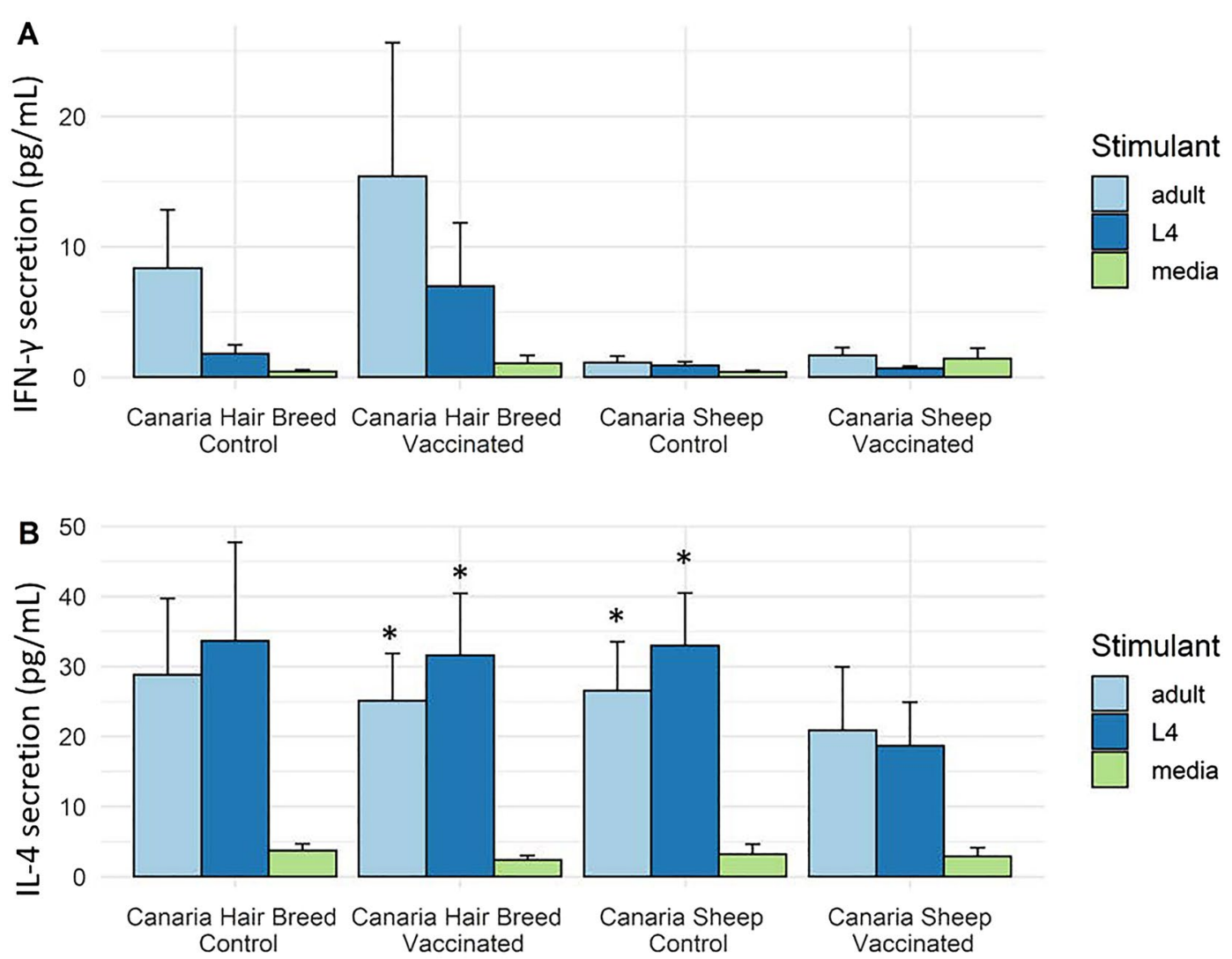

Figure 2 IFN- $\gamma$ and IL-4 secretion by abomasal lymph node lymphocytes following stimulation with Teladorsagia circumcincta L4 or adult somatic antigen from Canaria Hair Breed and Canaria Sheep vaccinated with a prototype recombinant sub-unit $T$. circumcincta vaccine and subsequently challenged with $T$. circumcincta. IFN- $\gamma(\mathbf{A})$ and IL-4 (B) secretion was examined in supernatants collected 4 days post-stimulation of abomasal lymph node lymphocytes with $5 \mathrm{~g} / \mathrm{mL}$ of T. circumcincta $L 4$ or adult somatic antigen. Data are expressed as the concentration of the cytokine release in picograms per $\mathrm{mL}(\mathrm{pg} / \mathrm{mL})$. Results are shown as the mean values with error bars indicating $\pm S E .{ }^{~}{ }^{* \prime \prime}$ denotes statistical significance for $p<0.05$ when compared to media only secretion.

In the work presented here, the reduction of worm length and EIU in vaccinated CS groups was negatively correlated with levels of IgA and $\mathrm{IgG}_{2}$ specific for extracts of L4 stage $T$. circumcincta. The role of IgA in protection of sheep against $T$. circumcincta has been proposed in previous studies of natural immunity, where it has been related to regulating worm growth targeting the L4 stage of this parasite [1, 17]. Several studies have associated $\operatorname{IgA}, \operatorname{IgG}_{1}$ and $\operatorname{IgE}$ with natural resistance against several GIN in sheep $[18,19]$. $\operatorname{IgG}_{2}$ has been also associated with natural protection against larval stages of Trichostrongylus colubriformis in genetically resistant sheep [20]. Interestingly, high levels of total IgG against L4 and excretory/secretory (ES) antigens of L4 were observed in Texel crossbred after vaccination [8]. Production of specific IgA against L4 $T$. circumcincta was also increased in vaccinated CHB. All the data suggest that a humoral response against L4 antigens is a consistent response possibly induced by this vaccine, which is logical as many of the antigens were selected based on their reactivity with IgA in the abomasal lymph or mucus from immune sheep [8], although abomasal lymph node cells were more strongly stimulated by adult $T$. circumcincta antigens than by L4 antigens, potentially due to immunomodulatory and/or suppressive molecules within L4 [21].

Globule leukocytes are considered to be activated mast cells [22]. Correlation studies also suggest a role for GL in the protection conferred by the vaccine in both breeds, and levels of this cell type were also negatively correlated with some elements of the parasitology in control groups. IL-4 is a key cytokine in mast cell maturation and, in agreement with histological data, it was also identified at high levels in ALN cells in all groups, independent of breed or vaccination status, following exposure to L4 and adult antigens. Globule leukocytes have been previously associated with resistance against GIN in animals naturally resistant to $T$. circumcincta $[23,24]$, generating a rapid larval rejection [25]. The data obtained here suggest that the vaccine confers protection in these breeds 


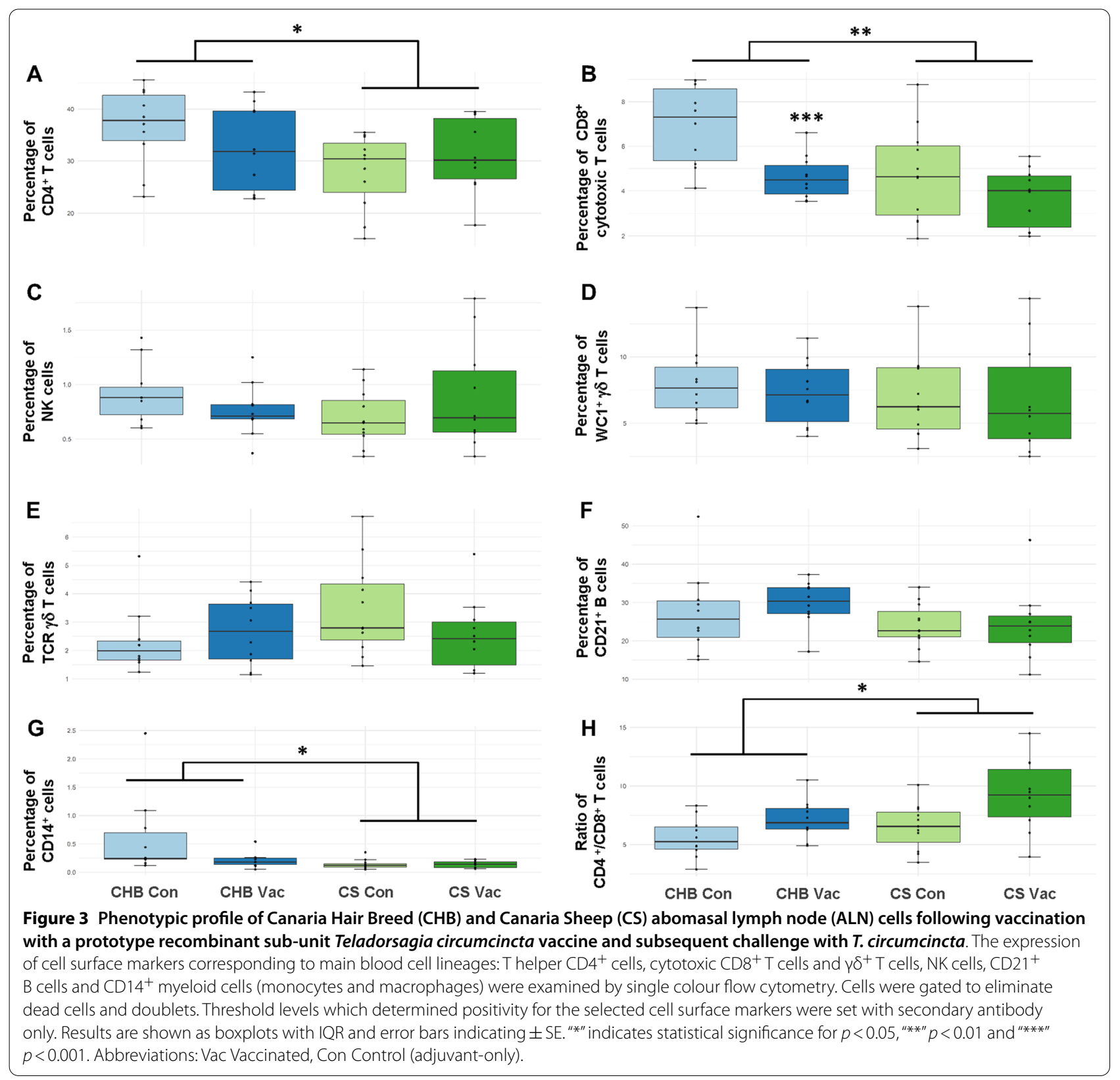

partly through improving mostly "natural mechanisms" of protection.

This vaccine prototype has now protected Texel crossbred lambs in five different trials [9] and, in this assay, also CS lambs were significantly protected. In $\mathrm{CHB}$, all parasitological parameters were reduced in vaccinated group, although the reductions were not statistically significant compared to the control group. With the current data, it is not possible to confirm if the $\mathrm{CHB}$ lambs did not respond to the vaccine or if this breed is so naturally resistant to $T$. circumcincta that the vaccine could not add extra protection. In fact, the adjuvant-only control CHB group harboured fewer and shorter worms and excreted fewer eggs than either vaccinated or control CS lambs. Cellular and humoral response studied in this trial were, however, very similar between the breeds, with ALN cells from both breeds releasing IFN- $\gamma$ and IL- 4 following stimulation with larval and adult worm antigens. This indicates that in both breeds, infection with $T$. circumcincta induced a mixed $\mathrm{T}$ helper type 1 (Th1) / Th2 immune response, with possibly higher levels of IFN- $\gamma$ produced by $\mathrm{CHB}$ lambs. While Th1 immunity, characterised by IFN- $\gamma$, has been linked with susceptibility to gastrointestinal 

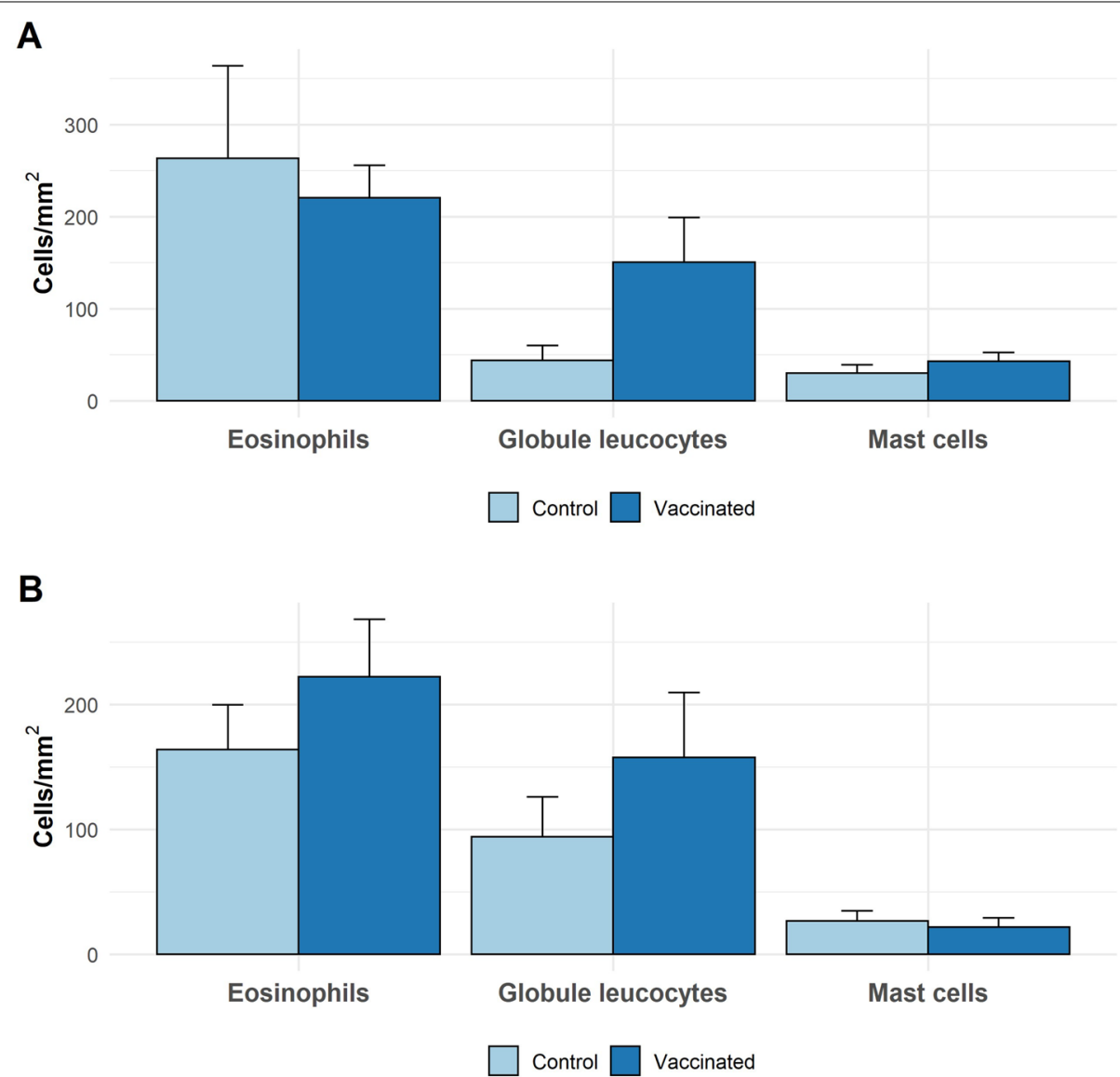

Figure 4 Eosinophils, globule leucocytes and mast cells in the abomasal wall in Canaria Sheep (A) and Canaria Hair Breed (B) following vaccination with a prototype recombinant sub-unit Teladorsagia circumcincta vaccine and subsequent $T$. circumcincta challenge. Values shown as means (cells $/ \mathrm{mm}^{2}$ ) \pm SEM in abomasal tissue obtained at post-mortem following vaccination and parasite challenge.

nematodes [26], other studies indicate that Th1 immunity can be linked with resistance to $H$. contortus, for

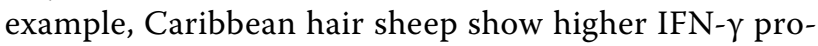
duction than susceptible sheep at 4 weeks post-infection [27]. More recently, a study in Creole goats has shown that resistance to $H$. contortus is associated with an upregulation of Th1 immune associated genes by 5 weeks post-infection, but that infection induces similar Th2 immune responses in resistant and susceptible goats [28]. These results provide growing evidence that a mixed Th1/Th2 immune response may be optimal for protection against ruminant GIN.

The main differences in cellular immune phenotypes between the two breeds were observed in ALN cell populations at post-mortem, whereby the proportion of $\mathrm{CD} 4^{+}$ and $\mathrm{CD}^{+} \mathrm{T}$ cells within the ALN cells were higher in $\mathrm{CHB}$ lambs, and in particular the controls. $\mathrm{CD}^{+}: \mathrm{CD} 8^{+}$ ratios were also higher in vaccinated lambs of both breeds. These results suggest that the $\mathrm{CHB}$ induces stronger local adaptive immune responses, reflected by higher levels of recruitment to and expansion of T cells within the ALN. It also indicates that vaccination via the systemic route has had some influence on the balance of $\mathrm{CD}^{+}$and $\mathrm{CD} 8^{+} \mathrm{T}$ cells within the $\mathrm{LN}$ draining the site of infection, with a greater proportion of $\mathrm{CD} 4^{+} \mathrm{T}$ cells possibly reflecting reactivation of memory $\mathrm{CD} 4^{+} \mathrm{T}$ cells primed by the vaccine. While induction of mucosal immune responses via the systemic route is generally ineffective, this has previously been shown for O. ostertagi, a GIN of cattle closely related to T. circumcincta, where intra-muscular immunisation of cattle with native ASP-1 and Quil A induced antigen-specific proliferation of natural killer (NK) cells in the abomasal mucosa [29]. Interestingly, this $\mathrm{NK}$ response was lost when the antigen was formulated with $\mathrm{Al}(\mathrm{OH})_{3}$, suggesting that the Quil A adjuvant, which was also used in this study, may be critical for systemically induced priming of the abomasal immune response.

As pointed out above, it would be desirable to reduce the number of recombinant proteins for commercial 

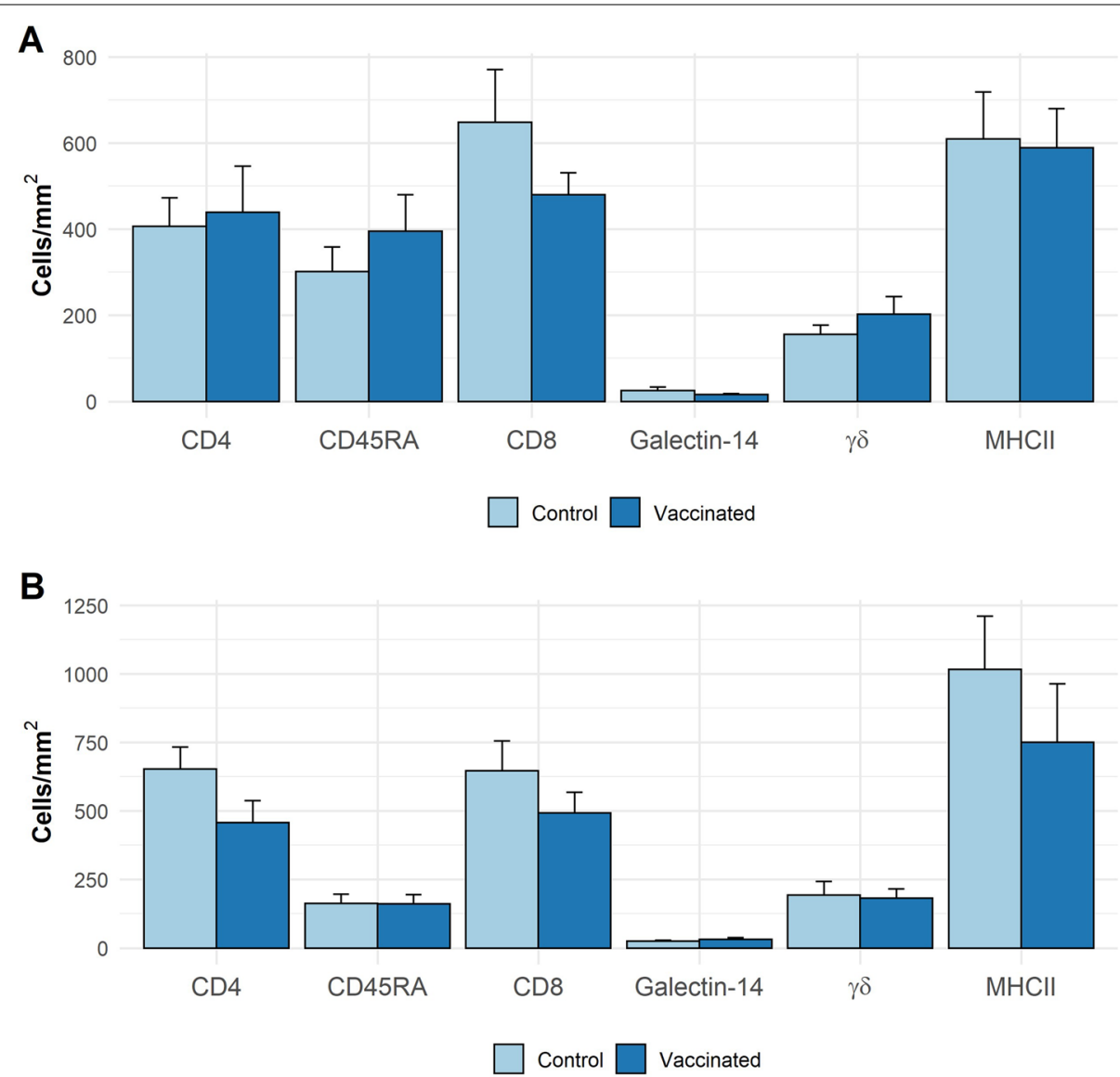

Figure 5 CD4, CD45RA, CD8, galectin-14, $\gamma \delta$ and MHCll positive cells in the abomasal mucosa in Canaria Sheep (A) and Canaria Hair Breed (B) following vaccination with a prototype recombinant sub-unit Teladorsagia circumcincta vaccine and subsequent $T$. circumcincta challenge. Values shown are means $\left(c e l l s / \mathrm{mm}^{2}\right) \pm S E M$ in abomasal tissue obtained at post-mortem following vaccination and parasite challenge.

purposes [9]. Previous trials performed with Texel crossbred lambs have indicated Tci-APY-1 and Tci-MEP-1 as the most promising candidates for inclusion in a simplified vaccine for T. circumcincta [9]. Immunoglobulin levels and/or antibody:antigen avidity, relationship with

Table 4 Relationship between globule leukocytes and parasitological variables in Canaria Sheep (CS) and Canaria Hair Breed (CHB) sheep vaccinated with a prototype recombinant sub-unit Teladorsagia circumcincta vaccine and subsequently challenged with $T$. circumcincta

\begin{tabular}{lllll}
\hline Group & $\begin{array}{l}\text { Cumulative } \\
\text { FEC }\end{array}$ & Worm burden & Worm length & EIU \\
\hline CS Vac & $-0.811^{* *}$ & $-0.608^{*}$ & $-0.776^{* *}$ & $-0.734^{* *}$ \\
CS Con & -0.409 & -0.182 & $-0.764^{* *}$ & -0.545 \\
CHB VaC & -0.545 & -0.555 & -0.309 & -0.285 \\
CHB Con & $-0.664^{*}$ & $-0.630^{*}$ & -0.340 & -0.364 \\
\hline
\end{tabular}

Significant correlations are represented with "*" at $p<0.05$ and "**" at $p<0.01$. parasitological parameters and recognition by adjuvantonly control lambs as they developed immunity following challenge, were the criteria for selecting these two proteins from the whole cocktail. The administration of TciMEP-1 and a mutated version of Tci-APY-1 performed as well as the whole vaccine prototype in Texel crossbred [9]. Tci-MEP-1 may also have a protective role in CS and $\mathrm{CHB}$ sheep in the trial presented here because in both breeds, specific serum IgA against this protein was negatively associated with parasitological parameters. The IgA response to Tci-APY-1 also showed negative associations with worm burden in $\mathrm{CHB}$ sheep. It seems that these two proteins could have a role in protection conferred by this prototype.

However, data obtained with $\mathrm{CS}$ and $\mathrm{CHB}$ lambs showed some slightly different responses. In CS, following similar criteria, Tci-SAA-1 and Tci-ASP-1 would also be good candidates, because IgG $_{1}$ against both proteins and $\mathrm{IgG}_{2}$ to Tci-ASP-1 was also negatively correlated with EIU. Interestingly, in Texel cross bred lambs, 
in which no differences in worm length were detected [7], these associations were not observed. This could mean breed differences in vaccine protective mechanisms. Future studies must clarify why this response was apparently breed-dependent as it appears that the host breed is important in this response. Considering the humoral response, therefore, it is not clear which recombinant protein(s) should be selected to ensure protective immunity across several breeds, although Tci-MEP-1, Tci-APY-1 are promising candidates that have also been successfully tested [9].

Some of these proteins may not induce a strong humoral response but could trigger a critical cellular response. In fact, some successful vaccine prototypes against related GIN develop their protective mechanisms through cellular responses [30-32]. Noticeably, GLs were negatively associated with protection in both vaccinated breeds in this trial.

In conclusion, this recombinant vaccine protected six-month-old CS breed lambs and did not significantly reduce parasitological parameters in $\mathrm{CHB}$ sheep. Globule leukocytes and IgA and $\operatorname{IgG}_{2}$ to L4 T. circumcincta antigens may be key mechanisms in protection conferred by the vaccine in the CS breed. Improving these responses at vaccination could reduce individual variability and enhance the response. Future studies considering sequential analysis of local immune response and/ or depleting particular cell populations, including serially diluted samples at different times of infection for refining antibodies measurement accuracy. All these studies would be desirable for improving this vaccine prototype.

\footnotetext{
Abbreviations

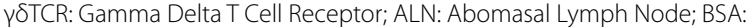
Bovine Serum Albumin; CHB: Canaria Hair Breed; CS: Canaria Sheep; ConA: Concanavalin A; DMSO: Dimethyl Sulfoxide; EIU: Eggs in utero; ES: Excretory/Secretory; FACS: Fluorescence-Activated Cell Sorting; FBS: Fetal Bovine Serum; FCS: Fetal Calf Serum; FEC: Faecal egg counts; GENLIN: Generalised Linear Models; GIN: Gastrointestinal nematodes; GL: Globule Leukocyte; GLM: General Linear Models; HBSS: Hank's Balanced Salt Solution; H. contortus: Haemonchus contortus; Ig: Immunoglobulin; IL-4: Interleukin 4; IL-17A: Interleukin 17A; IFN-ץ: Interferon gamma; L3: Third stage larval; L4: Fourth stage larval; LN: Lymph Node; LSA: Lymphocyte Stimulation Assays; LSD: Least Significance Difference; MHCII: Major Histocompatibility Complex II; M: Molar; NK: Natural Killer cells; OD: Optical Density; ODI: Optical Density Index; O. ostertagi: Ostertagia ostertagi; OPD: O-phenylene-diamine dihydrochloride; PBS: Phosphate buffered saline; RPMI: Roswell Park Memorial Institute medium; SEM: Standard error of the mean; SI: Stimulation Index; TBST: Tris Buffered Saline containing $0.1 \%$ Tween ${ }^{\circledR} 20$; T. circumcincta: Teladorsagia circumcincta; Tci-APY-1: Calciumdependent apyrase-1; Tci-ASP-1: Activation-associated secretory protein-1; TciCF-1: Cathepsin F-1; Tci-ES20: 20 KDa protein of unknown function; Tci-MEP-1: Astacin-like metalloproteinase-1; Tci-MIF-1: Macrophage migration inhibitory factor-1; Tci-SAA-1: An homologue of a protective antigen from Ancylostoma caninum; Tci-TGH-2: TGF homologue; Th1: T helper type 1; Th2: T helper type 2; TWM:Transport Wash Media; TMB: 3,3', 5, 5'-Tetramethylbenzidine.
}

\section{Supplementary Information}

The online version contains supplementary material available at https://doi. org/10.1186/s13567-021-00960-8.

Additional file 1. Antibody clones used for flow cytometry analysis and immunohistochemistry. "*" Antibody clone used for flow cytometry assays. "*** Antibody clone used for $1 \mathrm{HQ}$.

Additional file 2. Examples of abomasal mucosa sections from Canaria Hair Breed and Canaria Sheep experimentally infected with Teladorsagia circumcincta showing positive cells (x400). Haematoxylin and eosin staining for globule leukocyte in the upper layer $(\mathbf{A})$ and eosinophils in the basal layer (B), both indicated with arrows. Immunohistochemical staining with CD4+ antibody (SBU T4 pool $44.38+44.97$ ), showing CD4+ cells (arrows) in the apical (C) and basal area (D).

Additional file 3. IgA against vaccine proteins and their correlation with parasitology in Canaria Sheep lambs. Associations are expressed as Spearman's correlation coefficient. Same letters mean no significant differences between groups. Significant correlations are represented with "**" at $p<0.05$ and $" * * *$ at $p<0.01$.

Additional file 4. $\lg A$ against vaccine proteins and their correlation with parasitology in Canaria Hair Breed lambs. Associations are expressed as Spearman's correlation coefficient. Same letters mean no significant differences between groups. Significant correlations are represented with" "** at $p<0.05$ and "**" at $p<0.01$.

Additional file 5. IgG1 against vaccine proteins and their correlation with parasitology in Canaria Sheep lambs. Associations are expressed as Spearman's correlation coefficient. Same letters mean no significant differences between groups. Significant correlations are represented with "** at $p<0.05$ and "**" at $p<0.01$

Additional file 6. IgG1 against vaccine proteins and their correlation with parasitology in Canaria Hair Breed lambs. Associations are expressed as Spearman's correlation coefficient. Same letters mean no significant differences between groups. Significant correlations are represented with "**" at $p<0.01$

Additional file 7. IgG2 against vaccine proteins and their correlation with parasitology in Canaria Sheep lambs. Associations are expressed as Spearman's correlation coefficient. Same letters mean no significant differences between groups. Significant correlations are represented with "*" at $p<0.05$ and $^{\prime * * * " a t ~} p<0.01$.

Additional file 8. $\lg \mathrm{G} 2$ against vaccine proteins and their correlation with parasitology in Canaria Hair Breed lambs. Associations are expressed as Spearman's correlation coefficient. Same letters mean no significant differences between groups. Significant correlations are represented with "*" at $p<0.05$ and "**" at $p<0.01$.

Additional file 9. Correlations between cells and parasitological variables in Canaria Sheep lambs. Associations are expressed as Spearman's correlation coefficient. Significant correlations are represented with "** at $p<0.05$.

Additional file 10. Correlations between cells and parasitological variables in Canaria Hair Breed lambs. Associations are expressed as Spearman's correlation coefficient.

Additional file 11: Interleukin-17A secretion by abomasal lymph node lymphocytes following stimulation with Teladorsagia circumcincta L4 or adult somatic antigen from Canaria Hair Breed and Canaria Sheep vaccinated with a prototype recombinant sub-unit $T$. circumcincta vaccine and subsequently challenged with $T$. circumcincta. IL-17A secretion was examined in supernatants collected 4 days post-stimulation of abomasal lymph node lymphocytes with $5 \mu \mathrm{g} / \mathrm{mL}$ of T. circumcincta $L 4$ or adult somatic antigen. In general, antigen-specific IL$17 \mathrm{~A}$ release was not detected in any of the ALN cultures. N/D IL-17A were not detected, N/S no sampled availability. 


\section{Acknowledgements}

We thank Drs Piedrafita and Meeusen (Federation University, Australia) for kindly donating several antibodies used in this study, to Dr Conde, ULPGC (Spain), for assisting in cell collection at slaughtering and Alison Morrison, Moredun Research Institute for the production of T. circumcincta larvae.

\section{Authors' contributions}

AN, TMCN, JBM and JFG participated in the design of the study. JNH, CM, TPH, JFG carried out the experiments at ULPGC. YCM carried out LSA assays, cytokine ELISAs and flow cytometry at MRI. HWW, YCM assisted JNH, CM, TPH and JFG with post-mortem procedures. DGP prepared the recombinant proteins. AJN assisted JNH in vaccine preparation and administration. JNH and JFG coordinated the experiment. CM, JNH, ADH, YCM, JFG, TMCN, AJN and JBM participated in data analysis. CM, JNH and JFG drafted the manuscript. All authors read and approved the final manuscript.

\section{Funding}

This project received funding from the European Union's Horizon 2020 Research and Innovation Programme under Grant Agreement No 635408 ("PARAGONE: vaccines for animal parasites"). Cynthia Machín was the recipient of a fellowship funded by "Agencia Canaria de Investigación, Innovación y Sociedad de la Información de la Consejería de Economía, Industria, Comercio y Conocimiento" (ACIISI) and European Social Fund (ESF) Integrated Operational Programme for the Canary Islands 2014-2020, axis 3, priority theme 74 (85\%). She was also initially sponsored by "Fundación Canaria Universitaria de Las Palmas (FULP)" and "La Caixa"Bank. Tara Pérez-Hernández was supported by "Universidad de Las Palmas de Gran Canaria" and "Cabildo Insular de Gran Canaria" as PhD student in the ULPGC Predoctoral Training Program.

\section{Declarations}

\section{Ethics approval and consent to participate}

Experiments were approved by the Animal Welfare Ethics Committee of the Universidad de Las Palmas de Gran Canaria (OEBA_ULPGC_003_2014) and from the local authorities, following the rules of the Spanish Legislation (RD 53/2013). Several animals presented local granulomas in the injection area. They were followed by the researchers and all of them resolved and they had no systemic consequences. One lamb in the CHB-vaccine group died a few days after the start of the procedure from a post-traumatic renal haemorrhage. It was not related to animal handling. We followed the ARRIVE guidelines published in the online journal PLoS Biology in June 2010.

\section{Competing interests}

The authors declare that they have no competing interests.

\section{Author details}

${ }^{1}$ Facultad de Veterinaria, Instituto Universitario Sanidad Animal y Seguridad Alimentaria, Universidad de Las Palmas de Gran Canaria, Arucas, Spain. ${ }^{2}$ Moredun Research Institute, Edinburgh, UK. ${ }^{3}$ Roslin Technologies, Edinburgh, UK.

Received: 1 February 2021 Accepted: 20 May 2021

Published online: 16 June 2021

\section{References}

1. Stear MJ, Bishop SC, Doligalska M, Duncan JL, Holmes PH, Irvine J, McCririe L, McKellar QA, Sinski E, Murray M (1995) Regulation of egg production, worm burden, worm length and worm fecundity by host responses in sheep infected with Ostertagia circumcincta. Parasite Immunol 17:643-652

2. Stear MJ, Bishop SC (1999) The curvilinear relationship between worm length and fecundity of Teladorsagia circumcincta. Int J Parasitol 29:777-780

3. McRae KM, Stear MJ, Good B, Keane OM (2015) The host immune response to gastrointestinal nematode infection in sheep. Parasite Immunol 37:605-613

4. Smith WD, Jackson F, Jackson E, Williams J (1985) Age immunity to Ostertagia circumcincta: Comparison of the local immune responses of 4 $1 / 2$ - and 10-month-old lambs. J Comp Pathol 95:235-245
5. Henderson NG, Stear MJ (2006) Eosinophil and IgA responses in sheep infected with Teladorsagia circumcincta. Vet Immunol Immunopathol 112:62-66

6. Vercruysse J, Charlier J, Van Dik J, Morgan ER, Geary T, von SamsonHimmelstjerna G, Claerebout E (2018) Control of helminth ruminant infections by 2030. Parasitol 145:1655-1664

7. Nisbet AJ, McNeilly TN, Greer AW, Bartley Y, Oliver EM, Smith S, PalareaAlbaladejo J, Matthews JB (2016) Protection of ewes against Teladorsagia circumcincta infection in the periparturient period by vaccination with recombinant antigens. Vet Parasitol 228:130-136

8. Nisbet AJ, McNeilly TN, Wildblood LA, Morrison AA, Bartley DJ, Bartley Y, Longhi C, McKendrick IJ, Palarea-Albaladejo J, Matthews JB (2013) Successful immunization against a parasitic nematode by vaccination with recombinant proteins. Vaccine 31:4017-4023

9. Nisbet AJ, McNeilly TN, Price DRG, Oliver EM, Bartley Y, Mitchell M, PalareaAlbaladejo J, Matthews JB (2019) The rational simplification of a recombinant cocktail vaccine to control the parasitic nematode Teladorsagia circumcincta. Int J Parasitol 49:257-265

10. Matthews JB, Geldhof P, Tzelos T, Claerebout E (2016) Progress in the development of subunit vaccines for gastrointestinal nematodes of ruminants. Parasite Immunol 38:744-753

11. González JF, Hernández JN, Machín C, Pérez-Hernández T, Wright HW, Corripio-Miyar Y, Price D, Matthews JB, McNeilly TN, Nisbet AJ (2019) Impacts of breed type and vaccination on Teladorsagia circumcincta infection in native sheep in Gran Canaria. Vet Res 50:29

12. MAFF (1989) Manual of Veterinary Parasitological Laboratory Diagnostic Techniques, third ed. Ministry of Agriculture, Fisheries and Food, London

13. Smith SK, Nisbet AJ, Meikle L, Inglis N, Sales J, Beynon RJ, Matthews JB (2009) Proteomic analysis of excretory/secretory products released by Teladorsagia circumcincta larvae early post-infection. Parasite Immunol 31:10-19

14. Strain SA, Stear MJ (2001) The influence of protein supplementation on the immune response to Haemonchus contortus. Parasite Immunol 23:527-531

15. Hernández JN, Meeusen E, Stear M, Rodríguez F, Piedrafita D, González JF (2017) Modulation of Haemonchus contortus infection by depletion of $\gamma^{+} \mathrm{T}$ cells in parasite resistant Canaria Hair Breed sheep. Vet Parasitol 237:57-62

16. Britton C, Emery D, McNeilly TN, Nisbet AJ, Stear MJ (2020) The potential for vaccines against scour worms of small ruminants. Int J Parasitol 50:533-553

17. Stear MJ, Boag B, Cattadori I, Murphy L (2009) Genetic variation in resistance to mixed, predominantly Teladorsagia circumcincta nematode infections of sheep: from heritabilities to gene identification. Parasite Immunol 31:274-282

18. Stear MJ, Bairden K, Innocent G, Mitchell S, Strain S, Bishop S (2004) The relationship between IgA activity against 4th stage larvae and density dependent effects on the number of 4th stage larvae of Teladorsagia circumcincta in naturally infected sheep. Parasitol 129:363-369

19. Shaw RJ, Morris CA, Green RS, Wheeler M, Bisset SA, Vlassoff A, Douch PGC (1999) Genetic and phenotypic relationships among Trichostrongylus colubriformis-specific immunoglobulin E, anti-Trichostrongylus colubriformis antibody, immunoglobulin G1, faecal egg count and body weight traits in grazing Romney lambs. Livest Prod Sci 58:25-32

20. Pernthaner A, Cole SA, Morrison L, Green R, Shaw RJ, Hein WR (2006) Cytokine and antibody subclass responses in the intestinal lymph of sheep during repeated experimental infections with the nematode parasite Trichostrongylus colubriformis. Vet Immunol Immunopathol 114:135-148

21. McNeilly TN, Rocchi M, Bartley Y, Brown JK, Frew D, Longhi C, McLean L, Mclntyre J, Nisbet AJ, Wattegedera S, Huntley JF, Matthews JB (2013) Suppression of ovine lymphocyte activation by Teladorsagia circumcincta larval excretory-secretory products. Vet Res 44:70

22. Nisbet AJ, Meeusen EN, González JF, Piedrafita DM (2016) Immunity to Haemonchus contortus and vaccine development. Adv Parasitol 93:353-396

23. Gruner L, Cortet J, Sauvé C, Hoste H (2004) Regulation of Teladorsagia circumcincta and Trichostrongylus colubriformis worm populations by grazing sheep with differing resistance status. Vet Res 35:91-101

24. Albuquerque ACA, Bassetto CC, Almeida FA, Almeida FA, Hildersley KA, McNeilly TN, Britton C, Amarante AFT (2019) Differences in immune 
responses to Haemonchus contortus infection in the susceptible lle de France and the resistant Santa Ines sheep under different anthelmintic treatments regimens. Vet Res 50:104

25. Balic A, Bowles VM, Meeusen ENT (2000) The immunobiology of gastrointestinal nematode infections in ruminants. Adv Parasitol 45:181-241

26. Hassan M, Hanrahan JP, Good B, Mulcahy G, Sweeney T (2011) A differential interplay between the expression of Th1/Th2/Treg related cytokine genes in Teladorsagia circumcincta infected DRB $1 * 1101$ carrier lambs. Vet Res 42:45

27. MacKinnon KM, Burton JL, Zajac AM, Notter DR (2009) Microarray analysis reveals difference in gene expression profiles of hair and wool sheep infected with Haemonchus contortus. Vet Immunol Immunopathol 130:210-220

28. Aboshady HM, Mandonnet N, Félicité Y, Hira J, Fourcot A, Barbier C, Johansson AM, Jonas E, Bambou JC (2020) Dynamic transcriptomic changes of goat abomasal mucosa in response to Haemonchus contortus infection. Vet Res 51:44

29. González-Hernández A, Van Coppernolle S, Borloo J, Van Meulder F Paerewijck O, Peelaers I, Leclercq G, Claerebout E, Geldhof P (2016) Host protective ASP-based vaccine against the parasitic nematode Ostertagia ostertagi triggers NK cell activation and mixed lgG1-lgG2 response. Sci Rep 6:29496

30. Karanu FN, McGuire TC, Davis WC, Besser TE, Jasmer DP (1997) CD4+ T lymphocytes contribute to protective immunity induced in sheep and goats by Haemonchus contortus gut antigens. Parasite Immunol 19:435-445

31. González-Sánchez VM, Cuquerella M, Alunda JM (2018) Vaccination of lambs against Haemonchus contortus with the recombinant $\mathrm{HHC23}$ Effect of adjuvant and antigen dose. PLoS One 13:e0193118

32. González-Sánchez ME, Ndombasi-Bokuy M, Cuquerella M, Alunda JM (2019) Immunization with recombinant $\mathrm{rHc} 23$ partially protects lambs against trickle infections by Haemonchus contortus. BMC Vet Res 15:333

33. Maddox JF, Mackay CR, Brandon MR (1985) Surface antigens, SBU-T4 and SBU-T8 of sheep lymphocyte subsets defined by monoclonal antibodies. Immunology 55:739-748

34. Mackay CR, Beya MF, Matzinger P (1989) y/6 T cells express a unique surface molecule appearing late during thymic development. Eur J Immunol 19:1477-1483

35. Ballingall KT, Dutia BM, Hopkins J, Wright H (1995) Analysis of the fine specificities of sheep major histocompatibility complex class II-specific monoclonal antibodies using mouse I-cell transfectants. Anim Genet 26:79-84

\section{Publisher's Note}

Springer Nature remains neutral with regard to jurisdictional claims in published maps and institutional affiliations.
Ready to submit your research? Choose BMC and benefit from:

- fast, convenient online submission

- thorough peer review by experienced researchers in your field

- rapid publication on acceptance

- support for research data, including large and complex data types

- gold Open Access which fosters wider collaboration and increased citations

- maximum visibility for your research: over $100 \mathrm{M}$ website views per year

At BMC, research is always in progress.

Learn more biomedcentral.com/submissions 